\title{
ADAPTIVE SPACE OF JAVANESE TRADITIONAL HOUSE IN BRAYUT TOURISM VILLAGE YOGYAKARTA
}

\author{
V. R. Vitasurya ${ }^{1}$, Gagoek Hardiman ${ }^{2}$ and Suzanna Ratih Sari \\ Received: November $30^{\text {th }}, 2018$ \\ Accepted: March 8 $8^{\text {th }}, 2019$
}

\begin{abstract}
Traditional Javanese architecture, especially in rural areas, have undergone a major transformation. Transformation is owner's response to various conditions, such as the increasing number of family members, the improvement of social status and economic conditions, the needs of modernization and the consequences of being involved in government's programs. This paper aim is to examine how the owners of traditional houses respond to nowadays changes reflected through their houses designs. Brayut tourism village is a traditional settlement located at Yogyakarta's downtown area which is well known for its unique and well-preserved traditional Javanese houses. The transformation of traditional houses in Brayut is a combination of the need for change and persistence. On the one side, strong local traditions play a role in maintaining the elements of traditional houses and on the other side, dynamic modern needs play a role as a trigger for change. Adaptive space in the traditional house is a solution to this problem. The method used in this research is a case study on some Javanese traditional houses. An in-depth interview with the owners and mapping are also used to examine the chronology of traditional houses transformation. Transformation aspects are defined on the affected physical architecture elements. The result of this study is the transformation occurs on function and meaning of space as an adaptive response from the owners. While the shape of space and buildings, generally preserved as an effort to maintain the bond of traditions and trust.
\end{abstract}

Keywords: transformation, adaptive space, Javanese house, tourism village, traditional architecture.

\section{INTRODUCTION}

Traditional architecture is one of the traditional forms of local society. As a cultural product of local society, architecture represents social life in general and individual. (Maslucha, 2009). Needs and lifestyles of society change over time. For examples, an increasing number of family members, inheritance system and improvement of socioeconomic status can be the motifs for change. (Tarigan, 2013), (Ju, Kim, \& Ariffin, 2015). The phenomenon of architectural space and form transformation grow organically. (Tarigan, 2013). Javanese traditional building consists of 5 types based on roof types, i.e. Tajug, Joglo, Limasan, Kampung, and Panggangpe. Three of these types, Joglo, Limasan and Kampung, are mostly used for residential buildings. (Ismunandar, 1990). Javanese house represents social class from the owner. (Setyoningrum, Piliang, Santosa, Wahyudi, \& Java, 2015). Javanese house is not just a shelter but also has social value in Javanese culture, especially for the owner who builds it. (Cahyono, Setioko, \& Murtini, 2017). The high-class society builds their houses with Joglo roof (leader and noble class) and Limasan roof (trader and landlord class). While the low-class society builds their houses with Kampong roof (worker class). Pendopo (enclosed open space in front of the main house) is the symbol of power and authority which is identical with a wide and high roof. Pendopo has a function to connect the rule and rules relationship. (Kusno, 2006). In a rural area, cultural linkage gives

\footnotetext{
${ }^{1}$ Universitas Atma Jaya Yogyakarta

${ }^{2}$ Universitas Diponegoro Semarang
} 
the more effect to architectural transformation then it does to the physical linkage. (Pudianti, Syahbana, \& Suprapti, 2016). Space in Javanese traditional houses in the rural area still have a cultural function. For example, public space as social space accommodates kenduri (eating together to commemorate a special event in Javanese tradition) which sometimes even takes place at emper (the outer part of pendopo). (Sumardiyanto, Antariksa, \& Salura, 2016). Private space as sacred area, where the owner interacts with God, takes place at krobongan I senthong tengah (room in the center of the house). Krobongan is a salvation symbol of the owner.

In the modern era, internal factors such as owner needs related to the family or individual, are more dominant in the transformation process than the external factors i.e. government's programs and globalization. (Vitasurya, Hardiman, \& Sari, 2018). Building material, for example, is apart from the house which often undergoes a transformation. Traditional building materials such as good-quality bamboo and wood, are hard to find. The expert craftsman who did the traditional construction is also hard to find. So, owners of traditional houses often replace the traditional material with the modern ones. The usage of modern material in buildings also indicates the upgraded economic and social status of the owner. (Widaningsih \& Cahyani, 2015). Thus, a physical transformation took place simultaneously along with social transformations. (Mirmoghtadaee, 2009), (Cuthbert, 2013). Physical and functional transformation can be caused by the sifting of meaning according to current generations (the heirs of the house). People always have a tendency to return to their local culture which is displayed through the adaptation of the traditional characteristics. (Gopinath \& Kulkarni, 2014). The concept of Javanese traditional architecture could also be adapted to the function of the modern buildings. (Adiyanto, 2018). Limitations of domestic spaces in the traditional house could also mainly be encouraged by economic reasons and maintenance strategy of the occupants. (Al-Naim \& Mahmud, 2007). In the modern era, the traditional function cannot meet modern activity, so adaptive reuse becomes one of the solutions to preserve traditional houses. Adaptive reuse is a changing understanding of heritage not only as a witness of history but also as a source for the future, able to adapt to a changing society and incorporate new social values. (Keere \& Plevoets, 2018). The adaptive reuse of buildings - transforming them to meet new functional and aesthetic needs and requirements. (Plevoets \& Sowińska-Heim, 2018).

The development of sustainable tourism in the rural area is directed to develop the local potency which involves community participation. Alternative rural tourism attraction i.e. local culinary, traditional farming, cross country sport and trekking, homestay and local tradition event. (Soto PJ, 2013), (Hwang, Stewart, \& Ko, 2012), (Ivolga \& Erokhin, 2013). Homestay is the best choice for tourist in a rural area. Adaptive space in homestay can be done by re-function and develop the local house. Adaptive space that meets the modern needs of the owner is an effort to preserve the traditional house. The owners can be the heirs of the house, the buyer or renter. The commitment of tourism village development is a trigger to motivate owners to preserve their house. Adaptive space is an adjustment of function in the room of the traditional house. This research aim is to examine the adaptive space in five (5) traditional houses with Brayut tourism village as the case study. Adaptive space became a form of functional transformation in Brayut village. This research can be an alternative concept to preserve the Javanese traditional house in the development of sustainable rural tourism.

\section{Oveniew Brayut Tourism Village}

Brayut tourism village declares to be the first tourism village concept in Yogyakarta by Sri Sultan Hamengku Buwono X (Governor of DIY Province). This statement is at the same time with the East Asian Tourism Forum (EATOF) in Yogyakarta, 1999. Brayut was 
one of the tourist objects that was visited by the EATOF delegation. Javanese traditional houses in Brayut became the main attractions. "Concept of rural tourism based on tradition became an alternative to develop Brayut village in a sustainable way." said one of the local leader who initiated tourism village in Brayut. Located closely to Yogyakarta downtown (10 $\mathrm{km}$ from City Centre), Brayut became relatively affordable for tourists.

The transformation of traditional houses in Brayut is a partial process which is shown from the well-preserved building form although the functions, unfortunately, were changed. (Vitasurya, Hardiman, \& Sari, 2018). Transformation process involves tangible and intangible aspects. (Rudwiarti, Pudianti, \& Vitasurya, 2017). The sense of belonging is a strong motive for preserving the house. Family transitions driving the social change across generations became the main factor that affected the architectural transformation of a traditional house. (Charles, Davies, \& Harris, 2008). This condition also occurred in Brayut which was inhabited by builders from the second to the fourth generation. There are 24 wellpreserved Javanese traditional houses in Brayut. These houses represent 3 types of Javanese traditional houses (Joglo, Limasan, and Kampung). In this study, 5 houses are chosen to represent all of the traditional houses. Criteria on the 5 chosen cases are well maintained, complete and involved in tourism village program. There are Joglo 1, Joglo 2, Sinom 10, Limasan 11 and Kampung 9.

\section{Tourism development in Brayut Village}

Villagers are concerned about the use of local natural and cultural resources for tourism purposes and negative consequences. (Ghaderi \& Henderson, 2012). The community-based action is a meaningful impact of rural tourism development. It related with the capacity to protect the community from outside threats and foster development that aligns with the sense of community. This action involved local leader to drive the village potency. (Hwang et al., 2012), (Haven-Tang \& Jones, 2012). The development of sustainable tourism village became additional income for the villagers, therefore, the continuity of this program depends on community participation. (Trukhachev, 2015).

\section{METHOD}

This research used a case study method to examine adaptive space in 5 cases of traditional houses. This method is chosen because the chosen cases can show the ideal condition of the transformation of traditional houses in Brayut village. Investigation through chosen cases was done by mapping and reconstructing transformation process based on interviews with the owner. Case study method is suitable to answer research questions of how and why. (Yin, 2003). The cases are chosen by considering the conditions of the houses representing the 3 types of traditional house i.e. Joglo, Limasan, and Kampung.

\section{DISCUSSION}

This research discusses the transformation of traditional Javanese houses in Brayut village through 5 selected cases.

\section{Case 1, the transformation of Joglo 1}

Joglo 1 belong to the 1st lurah (village leader), who was one of the pioneers of Brayut Village. Built in 1890, this house was transformed in 2005 after 15 years being vacant. 


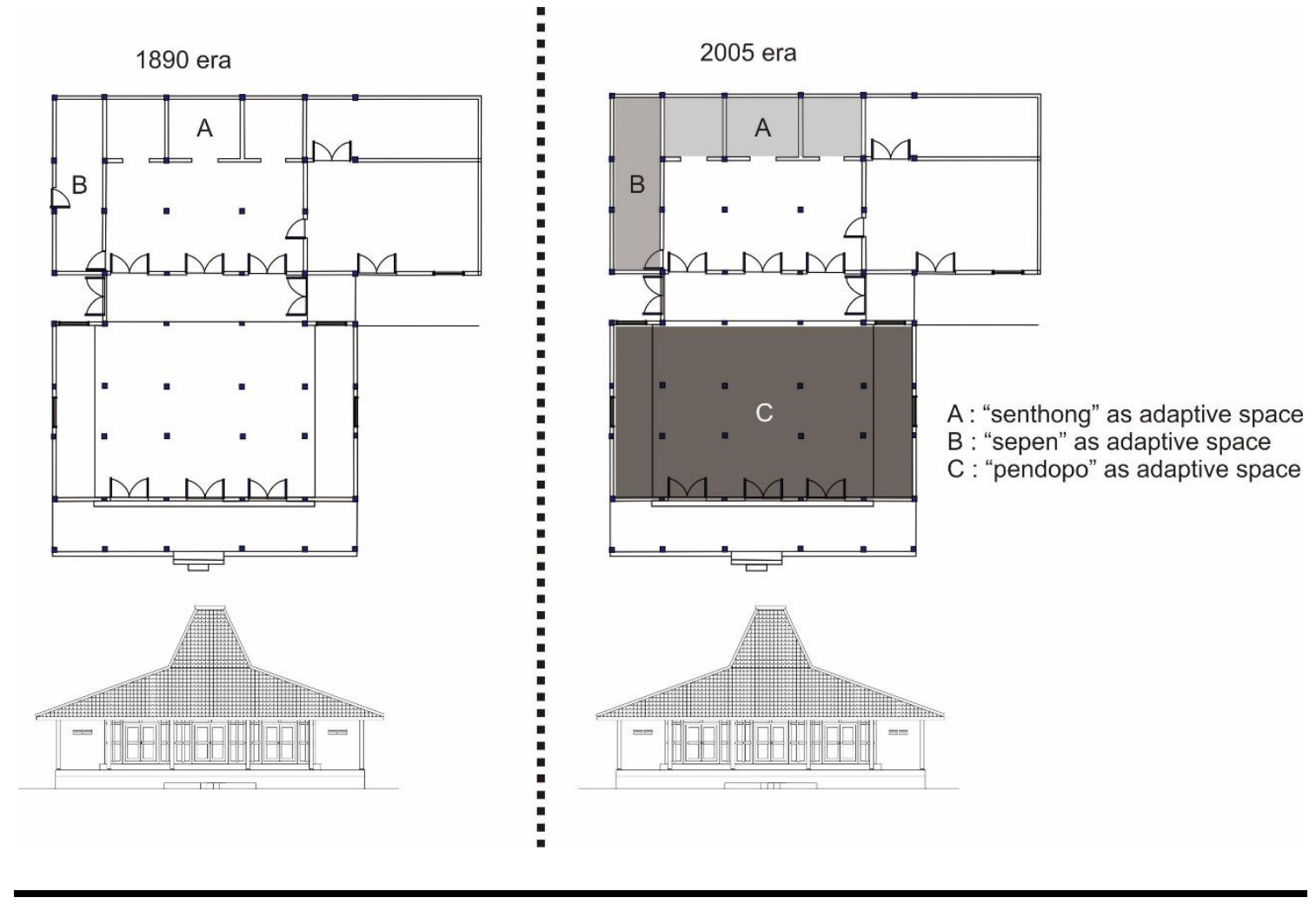

Figure 1. The transformation process of Joglo 1

In Joglo 1, adaptive space occurs in senthong (center of the house) and pendopo area. This house generally is transformed into a homestay facility. The Javanese house form is well preserved in a whole. Transformation process can be seen in Figure 1. The house function transforms as an adaptive response of the owner for the social and cultural change. In line with the concept of adaptive reuse to preserve the original shape but accommodate modern need (Plevoets \& Sowińska-Heim, 2018), the Joglo 1 does it as a commitment from the heirs to keep their ancestor legacy.

\section{Case 2, the transformation of Joglo 2}

Joglo 2 belongs to the 2nd lurah (village leader) in 1943 after in charge as a local leader. This house was limasan before the owner became lurah. The older limasan house was built in the 1900 era. Transformation process occurs in 3 eras, i.e. 1943, 1975 and 2005.

In Joglo 2, adaptive space occurs in gandhok (additional side building) and pendopo area. This house has partial transformation as a homestay and dwelling for the owner. The process can be seen in Figure 2. The owner transformed some parts of this house for tourist activity to response the tourism program and social-cultural change. Partial adaptation, in this case, represents the social status change of the owner. (Cuthbert, 2013). The house is well-preserved in general.

\section{Case 3, the transformation of Sinom 10}

Sinom 10 belongs to one of the local nobles but was inhabited by his niece. The owner's parents were a rich and honorable person in Brayut. The owner has passed away and this house was inherited to his children ( 7 brothers). The children lived in other cities, so they ask their aunt to maintain this house. The house is well preserved because of their respect to the parents and keep the family pride. The transformation process occurs in 1975 and 2005 era. 

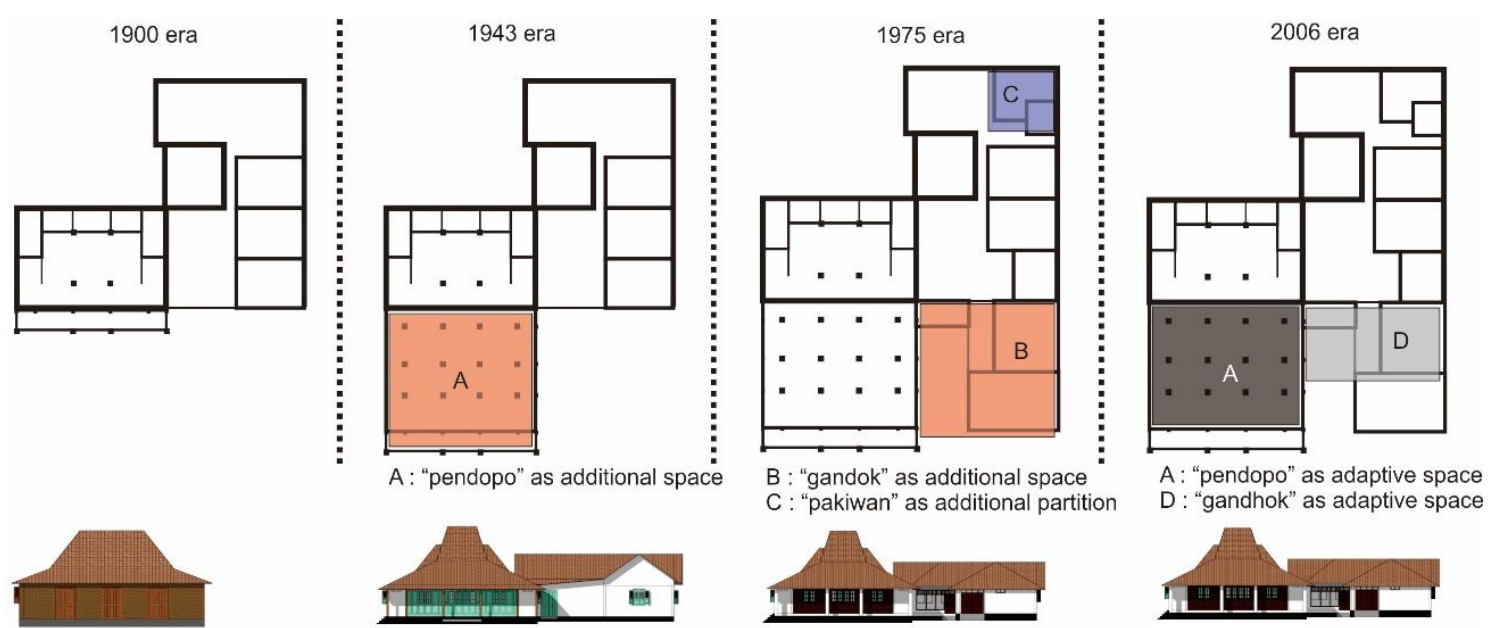

Figure 2. The transformation process of Joglo2

In sinom 10, adaptive space occurs in gandhok and pendopo area. This house has partial transformation as homestay and dwelling for the owner. The owner transformed some parts of this house for tourist activity to response the tourism program and socialcultural change. The transformation process of Sinom 10 can be seen in figure 3. Motif to response the tourism program in line with the social-cultural change in the modern era. (Ardiyanto, Djunaedi, Ikaputra, \& Suryabrata, 2014).

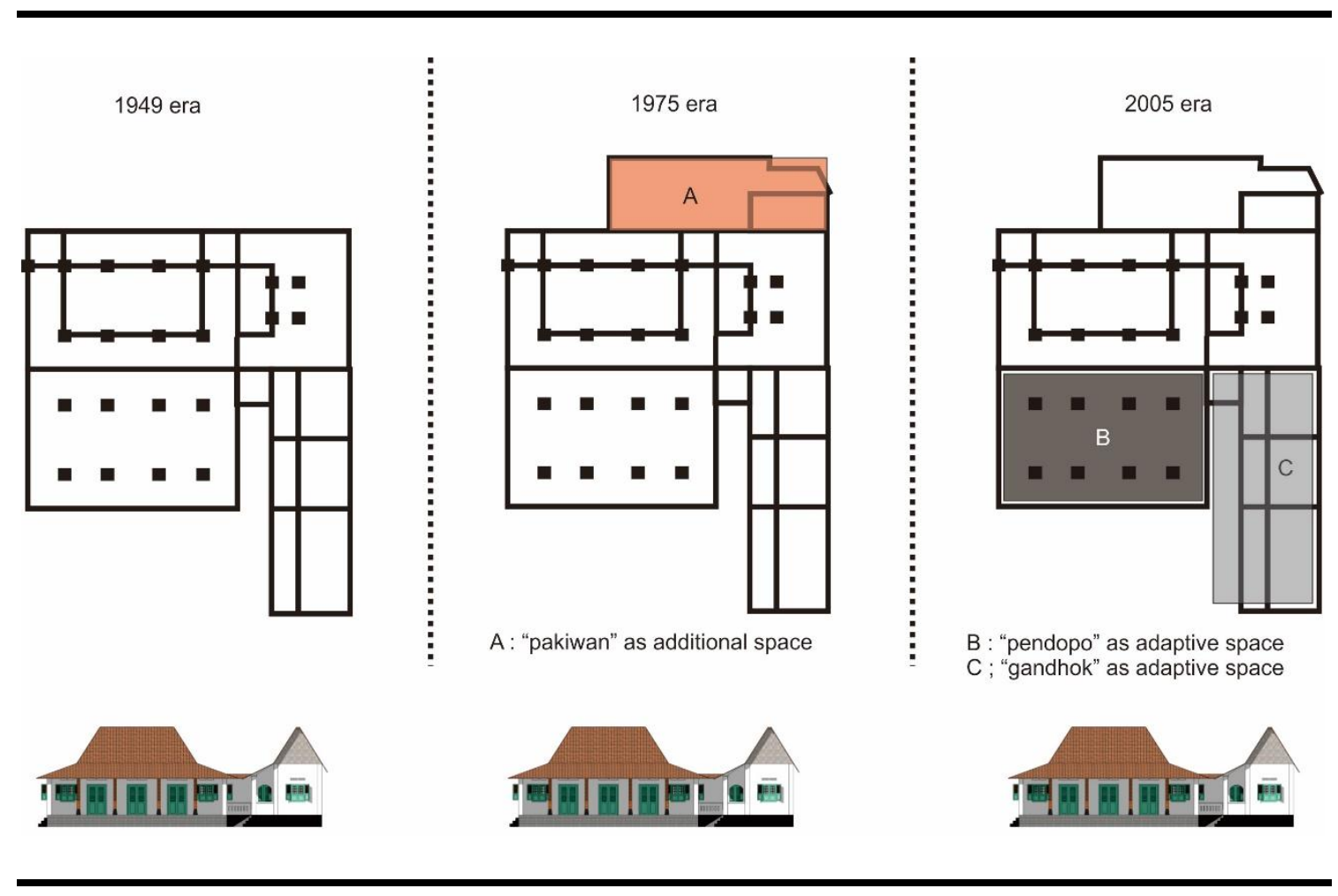

Figure 3. The transformation process of Sinom 10 
In this case, motif to change show in functional aspect, while in form and shape aspect is tend to unchanged. The house is well preserved in general.

\section{Case 4, transformation of Limasan 11}

Limasan 11 is the house of one of a local landlord. First, build in Limasan pokok (main structure of limasan house) then enlarge in 1962 with pendopo and gandok. The house is inhabited by the first son (from 6 brothers) and maintain it as a family house. The children maintain it as respect for the parents. In limasan 11, adaptive space occurs in gandhok area. This house has partial transformation as homestay and dwelling for the owner. The owner transformed some parts of this house for tourist activity to response the tourism program and social-cultural change.

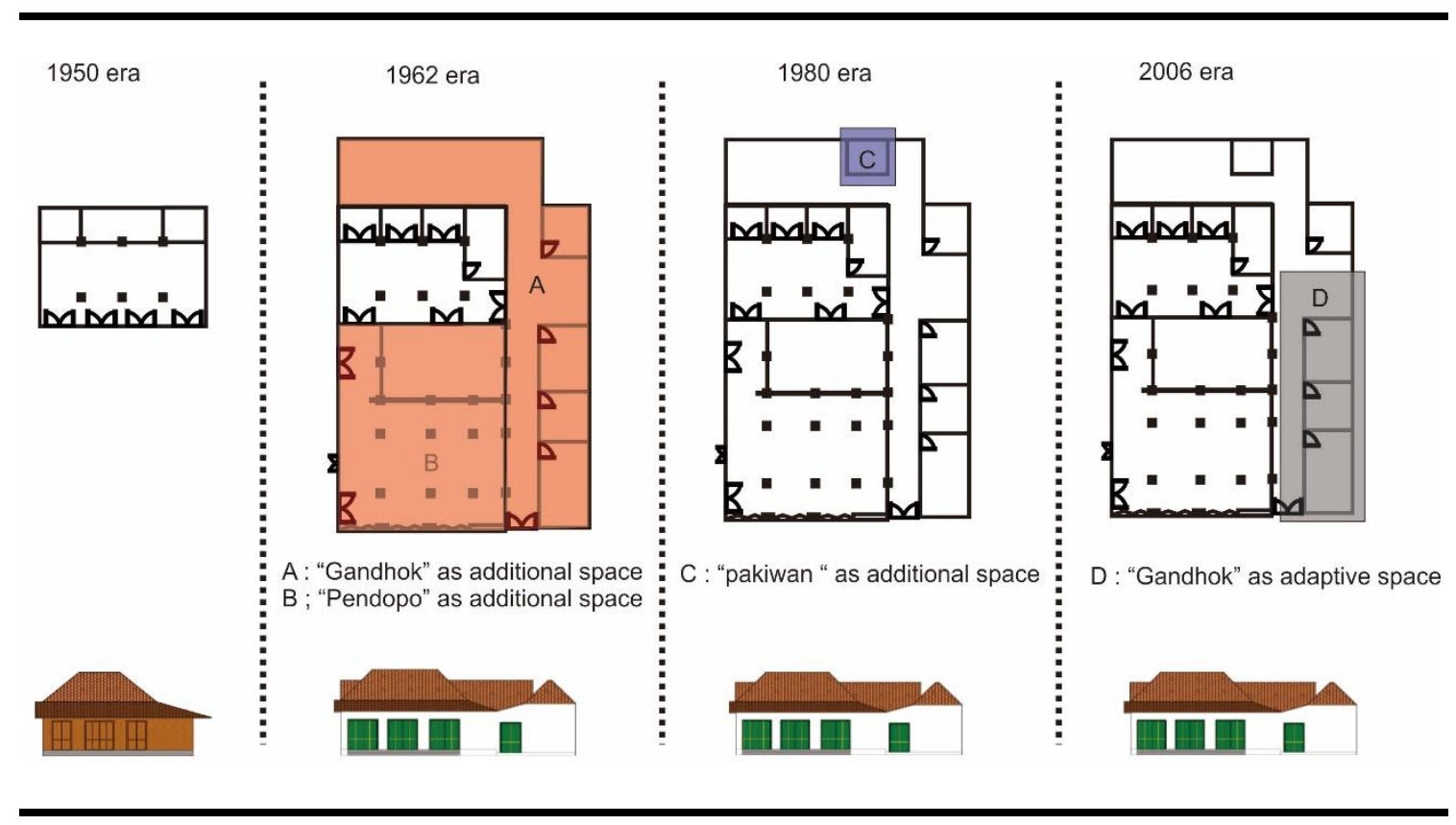

Figure 4. The transformation process of Limasan 11

The transformation of limasan 11 can be seen in figure 4 . In line with case 4 , the motif to change also was driven by the need to show the improvement of social-economic status as said by Cuthbert. (Cuthbert, 2013). The house is well preserved in general.

\section{Case 5, the transformation of Kampung 9}

Kampung 9 was built as a servant house. The house built in the $1^{\text {st }}$ lurah's land (on the right side of Joglo 1).

Kampung 9 was inhabited by the servant family of $1^{\text {st }}$ lurah. As a servant house, the family does not own the house, so when the owner died in 1980, all of his children moved to other cities. In 2005, another villager who involved in tourism program rented this house from the Joglo $1^{\text {st }}$ heirs, and turn it into tourism information office and shop.

In Kampung 9, adaptive space occurs in the whole house. The house was transformed into a public facility to support the tourism village program. The traditional shape of the house became a unique attraction functioned as an office and shop. This transformation is a response to social economic change as said by Cuthbert. (Cuthbert, 2013). But in this case, Kampong 9 which was inhabited by the renter, doesn't change in the shape and form aspect at all. The transformation of kampong 9 can be seen in figure 5 . The identification of the 
owner's response is showed through adaptive space in their houses as a transformation process.

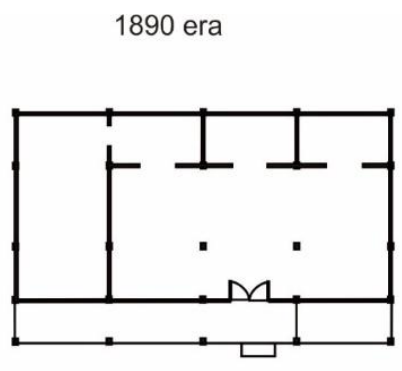

2005 era

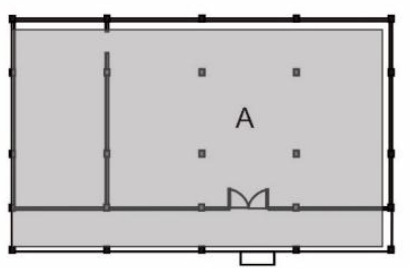

A : "ndalem " as adaptive space

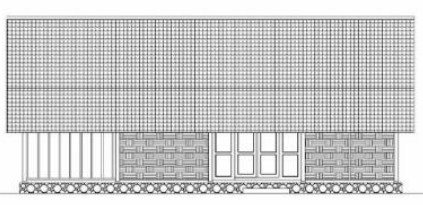

Figure 5. The Transformation process in Kampung 9

Table 1. Comparison of 5 cases Traditional House transformation in Brayut tourism village

\begin{tabular}{|c|c|c|c|c|}
\hline NO & Case & Transformation & Adaptive space & Adaptation response \\
\hline \multirow[t]{5}{*}{1} & Joglo 1 & $\begin{array}{l}\text { Dwelling function change to } \\
\text { accommodation function. } \\
\text { Leader symbolic meaning shift } \\
\text { to pride and obedient } \\
\text { meaning. }\end{array}$ & $\begin{array}{l}\text { Senthong } \\
\text { Sepen } \\
\text { Pendopo } \\
\text { (whole area) }\end{array}$ & $\begin{array}{l}\text { Culture social change as a } \\
\text { modernity response } \\
\text { Social economic change as an } \\
\text { economic improvement } \\
\text { response }\end{array}$ \\
\hline & Joglo 2 & $\begin{array}{l}\text { Dwelling function change to } \\
\text { accommodation and dwelling } \\
\text { function. } \\
\text { Leader symbolic meaning shift } \\
\text { to pride and obedient } \\
\text { meaning. }\end{array}$ & $\begin{array}{l}\text { Gandhok } \\
\text { Pendopo }\end{array}$ & $\begin{array}{l}\text { Culture social change as a } \\
\text { modernity response } \\
\text { Social economic change as an } \\
\text { economic improvement } \\
\text { response }\end{array}$ \\
\hline & Sinom 10 & $\begin{array}{l}\text { Dwelling function change to } \\
\text { accommodation and dwelling } \\
\text { function. } \\
\text { The high-class symbolic } \\
\text { meaning shift to obedient } \\
\text { meaning. }\end{array}$ & $\begin{array}{l}\text { Gandhok } \\
\text { Pendopo }\end{array}$ & $\begin{array}{l}\text { Culture social change as a } \\
\text { modernity response } \\
\text { Social economic change as an } \\
\text { economic improvement } \\
\text { response }\end{array}$ \\
\hline & $\begin{array}{l}\text { Limasan } \\
11\end{array}$ & $\begin{array}{l}\text { Dwelling function change to } \\
\text { accommodation and dwelling } \\
\text { function. } \\
\text { The high-class symbolic } \\
\text { meaning shift to obedient } \\
\text { meaning. }\end{array}$ & Gandhok & $\begin{array}{l}\text { Culture social change as a } \\
\text { modernity response } \\
\text { Social economic change as an } \\
\text { economic improvement } \\
\text { response }\end{array}$ \\
\hline & $\begin{array}{l}\text { Kampung } \\
9\end{array}$ & $\begin{array}{l}\text { Dwelling function change to } \\
\text { supporting function in Tourism } \\
\text { Village. } \\
\text { Low-class symbolic meaning } \\
\text { change to ownership meaning }\end{array}$ & Whole area & $\begin{array}{l}\text { Culture social change as a } \\
\text { modernity response } \\
\text { Social economic change as an } \\
\text { economic improvement } \\
\text { response }\end{array}$ \\
\hline
\end{tabular}

Research analysis, 2018 
Based on the comparison, shown in table 1, transformation in traditional house occurs in functional and meaning across generations while the basic shape of a traditional house tends to be unchanged. (see in figure 6). Shape transformation was caused by the social change of the heirs. (Cuthbert, 2013). In Javanese traditional house concept, this process shows the upgrading house typology. (see in figure 7).

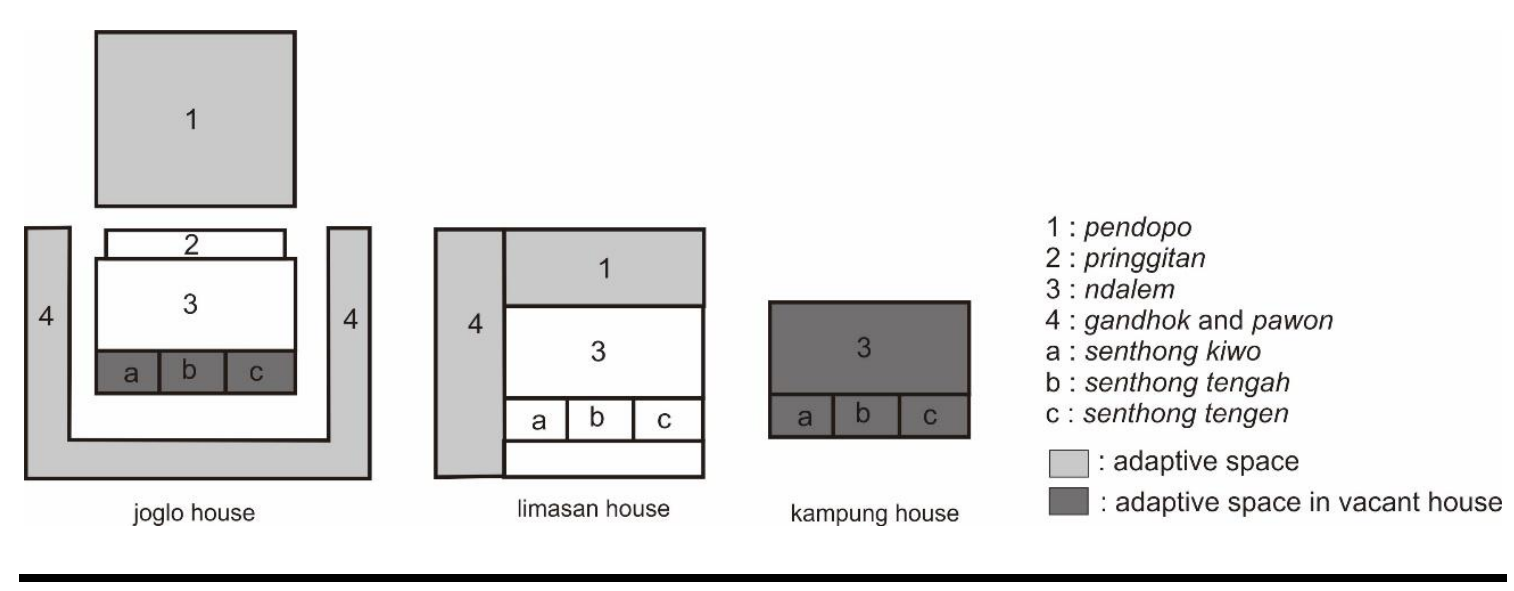

Figure 6. The Transformation of "adaptive space"

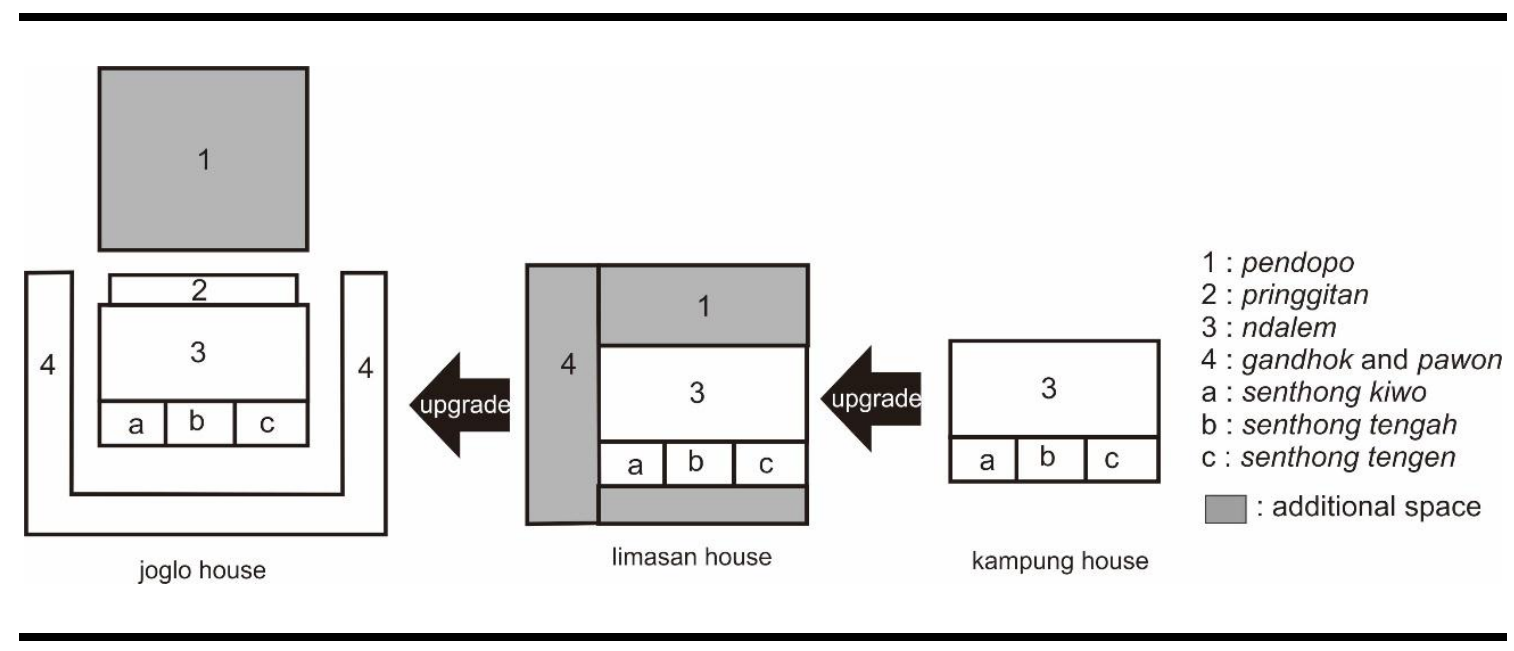

Figure 7. Transformation of "additional space"

The transformation process is an adaptive response of the heirs to meet modern needs. (Mirmoghtadaee, 2009). Old tradition and beliefs are no longer kept by the heirs such as krobongan served as sacred space. Transformation of a traditional house in Brayut tourism village defines more specific. In a functional aspect, senthong area became a bedroom for the owner or tourist. In the meaning aspect, the house as a symbol of identity for the builder shifts to be a symbol of pride and obedience of the heirs. There is a difference adaptation in senthong area. In the inhabited house, senthong area is not used for tourist attraction, but in a vacant house, senthong area became accommodation for tourist. This difference emerges because, in the inhabited house (Joglo 2, Sinom 10, Limasan 11), the ancestor message was kept and connected to the heirs in daily life. While this condition does not occur in the vacant house (Joglo 1 and Kampung 9). (see in figure 6). 


\section{CONCLUSION}

Adaptive space is a space where the owner can meet the change of modern needs and persist the originality of traditional Javanese house. Adaptive space as a form of transformation in Javanese traditional houses in Brayut Tourism Village can be described in functional aspect, adaptive space occurs in social culture and social economic change across generations of the heirs. The social culture change was driven by modernization and the change of mindset of the owner. The social economic change was driven by the tourism village program. This program can improve the economic value of the space in traditional houses.

Adaptive space also describe in meaning aspect, adaptive space occurs as the impact of changing mindset and belief of the modern generation. This change leads to the shift on the house meaning among the builders and their heirs.

In shape aspect, adaptive space shape tends to maintain the originality of the house. Efforts to preserve was driven by pride and obedience motivation of the heirs. This motivation is supporting factor to develop sustainable tourism village based on local tradition.

\section{ACKNOWLEDGMENTS}

Appreciation was given to Mrs. Wahini. Mrs. Arini, Mrs. Tris, Mr. Sukarman and Mr. Sudarmadi as owners and users of traditional houses in Brayut village. Also for the support from Laboratorium Perencanaan dan Perancangan Lingkungan dan Kawasan, Department of Architecture, Faculty of Engineering, Universitas Atma Jaya Yogyakarta.

\section{REFERENCES}

Adiyanto, J. (2018). Mencari DNA Arsitektur di Nusantara. In Seminar Arsitektur Nusantara IPLBI 2018. IPLBI.

Al-Naim, M., \& Mahmud, S. (2007). Transformation of traditional dwellings and income generation by lowincome expatriates: The case of Hofuf, Saudi Arabia. Cities, 24(6), 422-433. https://doi.org/10.1016/j.cities.2007.06.001

Cahyono, U. J., Setioko, B., \& Murtini, T. W. (2017). Transformation of form in the growth of modern Javanese house in Laweyan Surakarta. Journal of Architecture And Urbanism, 41(4), 288-295.

Charles, N., Davies, C. A., \& Harris, C. (2008). FAMILY IN TRANSITION - Social Change, family formation and kin relationship (1st ed.). Bristol: The Policy Press.

Cuthbert, A. (2013). Vernacular Transformation: Context, Issues, Debates. In G. A. M. Suartika (Ed.), VERNACULAR TRANSFORMATION Architecture, Place and Tradition (1st ed., pp. 7-39). Denpasar: Pustaka Larasan.

Ghaderi, Z., \& Henderson, J. C. (2012). Sustainable rural tourism in Iran: A perspective from Hawraman Village. Tourism Management Perspectives, 2-3, 47-54. https://doi.org/10.1016/j.tmp.2012.03.001

Gopinath, G., \& Kulkarni, S. . (2014). The Impact of Socio-Cultural Factors on the Transformation of the Residential Architecture of Kerala. International Journal of Research, 1(5), 526-530. Retrieved from http://edupediapublications.org/journals/index.php/ijr/article/view/189

Haven-Tang, C., \& Jones, E. (2012). Local leadership for rural tourism development: A case study of Adventa, Monmouthshire, UK. Tourism Management Perspectives, 4, 28-35. https://doi.org/10.1016/j.tmp.2012.04.006

Hwang, D., Stewart, W. P., \& Ko, D. (2012). Community Behavior and Sustainable Rural Tourism Development. Journal of Travel Research, 51(3), 328-341. https://doi.org/10.1177/0047287511410350

Ismunandar, R. (1990). Joglo-Arsitektur Rumah Tradisional Jawa (3rd ed.). Semarang: Dahara Prize.

Ivolga, A., \& Erokhin, V. (2013). Tourism as an Approach to Sustainable Rural Development in Post-Socialist Countries: A Comparative Study of Serbia and Slovenia. Economics of Agriculture, 60(4), 789-800. https://doi.org/10.3390/su10010054

Ju, S. R., Kim, B. M., \& Ariffin, S. I. (2015). Continuation and Transformation of Traditional Elements in Colonial Vernacular Houses in Kampong Bharu, Malaysia. Journal of Asian Architecture and Building Engineering, 14(2), 339-346. https://doi.org/10.3130/jaabe.14.339

Keere, N. Vande, \& Plevoets, B. (2018). Heritage without heirs? Reconnecting church and community through adaptive reuse. In M. Banks (Ed.), Interpret Europe's Conference 2018 - Proceedings (pp. 195-207). Kőszeg. 
Kusno, A. (2006). Guardian of memories : Gardu in urban Java. Indonesia, 81(81), 95-149.

Maslucha, L. (2009). KAMPUNG NAGA: Sebuah Representasi Arsitektur sebagai Bagian dari Budaya. ElHarakah, Vol. 11, No.1, Tahun 2009, 11(1), 35-49.

Mirmoghtadaee, M. (2009). Process of Housing Transformation in Iran. Journal of Construction in Developing Countries, 14(1), 69-80.

Plevoets, B., \& Sowińska-Heim, J. (2018). Community initiatives as a catalyst for regeneration of heritage sites: Vernacular transformation and its influence on the formal adaptive reuse practice. Cities, 78, 1-18. https://doi.org/10.1016/j.cities.2018.02.007

Pudianti, A., Syahbana, J. A., \& Suprapti, A. (2016). Role of Culture in Rural Transformation in Manding Village, Bantul Yogyakarta, Indonesia. In Procedia - Social and Behavioral Sciences (Vol. 227, pp. 458-464). The Author(s). https://doi.org/10.1016/j.sbspro.2016.06.101

Rudwiarti, L. A., Pudianti, A., \& Vitasurya, V. R. (2017). A Comparison Study of Tangible and Intangible Culture as Commercialisation Process of Tourism Village in Yogyakarta. E-Journal of Tourism, 4(2), 71-77.

Setyoningrum, Y., Piliang, Y. A., Santosa, I., Wahyudi, D., \& Java, W. (2015). HIERARCHICAL SOCIAL STRUCTURE AND THE SOCIAL SPACES FORMATION IN TRADITIONAL LIMASAN HOUSE OF JAVANESE MIDDLE-. The International Journal of Social Science, 32(1), 37-45.

Soto PJ, C. M. (2013). Preservation and Conservation of Rural Buildings as a Subject of Cultural Tourism: A Review Concerning the Application of New Technologies and Methodologies. Journal of Tourism \& Hospitality, 02(02). https://doi.org/10.4172/2167-0269.1000115

Sumardiyanto, Antariksa, \& Salura, P. (2016). MAKNA RUANG PUBLIK PADA RUMAH TRADISIONAL MASYARAKAT JAWA KASUS STUDI: DESA JAGALAN KOTAGEDE YOGYAKARTA. Jurnal Arsitektur NALARs, 15(1), 1-12. https://doi.org/10.24853/nalars.15.1.1-12

Tarigan, R. (2013). Pola Pembagian Lahan Pekarangan Di Rumah Tradisional Jawa Berdasar Sistem Pembagian Warisan, Studi Kasus: Jeron Beteng, Kraton, Yogyakarta. Jurnal Tesa Arsitektur, 11, 13. https://doi.org/10.24167/TES.V11I1.222

Trukhachev, A. (2015). Methodology for evaluating the rural tourism potentials: A tool to ensure sustainable development of rural settlements. Sustainability (Switzerland), 73), 3052-3070. https://doi.org/10.3390/su7033052

Vitasurya, V. R., Hardiman, G., \& Sari, S. R. (2018). Transformation of traditional houses in the development of sustainable rural tourism, case study of Brayut Tourism Village in Yogyakarta. In IOP Conference Series: Earth and Environmental Science (Vol. 106). https://doi.org/10.1088/1755-1315/106/1/012060

Widaningsih, L., \& Cahyani, D. (2015). Transformation of Traditional Village Architectural Values in Modern Sustainable Architecture Design. In International Conference on Innovation in Engineering and Vocational Education (pp. 99-103).

Yin, R.. K. (2003). Case Study Research : Design and Method(3rd ed.). California: Sage Publication. 